\title{
Analysis of the Risk from Finance of the New Campus Construction in Colleges and Universities
}

\author{
Lv Zhi xue ${ }^{1, \text { a }}$ \\ ${ }^{1}$ Jilin Jianzhu University, Planning and Finance department,Changchun,china \\ alvzhixue_2007@sina.com
}

\begin{abstract}
With the constant development of the cause of higher education in our country .The enlargement of enrollment scale, the existing education resources and educational.Condition already cannot satisfy the requirement of running a school under the new.Situation.in order to development,regardless pf the financial risk, some colleges and Universities have been raised to a new campus construction.In new campus construction.Therefore,how to strengthen the financial management,innovation of colleges and Universities the financing channels, to guard against and defuse financial riska,is worth Studying and college financial management is the important subject to be solved.
\end{abstract}

Keywords-List the keywords covered in your paper. These keywords will also be used by the publisher to produce a keyword index.

\section{INTRODUCTION}

With the rapid development of china's education ,higher education from elite education to Popularity ,popularize education transformation ,the development of colleges and universities in china has entered a "fast track".the original scale and operating conditions has been difficult to meet the needs of the development of colleges and universities under the new situation.In orderto make the healthy and universities to development of higher education enterprise in our country ,many colleges and universities to develop new campus construction the new campus construction the new ampus construction has greatly improved the condition and environment of colleges and scientific research ,has laid a solid foundation for the teaching and scientific research avtivities, but as a result of the new construction requires a lot of money, on its own financiare sources in universities is hard to meet, almost all the colleges and universities needs to be done through bank loans, has brought the heavyeconomic burden. As the construction scale, longer cycle, total liabilities also will more and more, once the financial management of the lack ofscientific nature, rationality, the outbreak of the possibility of financial risk is bigger and bigger, so is close to "bankruptcy" individual colleges and universities. Therefore, to strengthen financial management, improve the efficient use of funds, innovative financing channels, toevade and dissolve the financial risk effectively, to promote the healthy and sustainable development of colleges anduniversities is of great significance.

PROBLEMS EXISTING IN THE FINANCIAL MANAGEMENT IN THE CONSTRUCTION OF NEW CAMPUS OF UNIVERSITY

\section{A. the rationality of the financing problem}

Currently, the main source of income in colleges and universities including financial allocations, tuition revenue, the two parts more than money is used to meet the demand of the development of education. The university's new campus construction funds, most of them can only rely on oneself or financing from financial institutions. Many colleges and universities hope to continue to expand the scale of enrollment and further improve the tuition standard increase income to repay bank loans. In view of our country's current economic development level and population structure, the characteristics of nces funding is increased, but the continuous expansion of enrollment will be difficult. Combined with our country's higher education marketization is not high, not have the ability to market, their management ability is insufficient. So, as the recruitment of students scale to drop, less income, lower ability to repay bank loans. Once solvency risk highlighted, those who don't "tailored" scale and development situation of borrowing school, according to their own will got bogged down in too much debt, interest is too high, will seriously affect the healthy and continuous development of colleges and universities.

\section{B. applications is the reasonable and legal issues}

Capital operation in the construction of the new campus of rationality, legality has been closely watched. In recent years, the corruption case of repeated exposure caused by infrastructure projects in colleges and universities, has drawn great attention of the authorities. Due to the university's new campus construction need a lot of money, if used construction fund is not enough reasonable and legitimate, will cause a huge waste. Some schools in order to make image project, originally by rebuilding and expansion of some construction can reach the purpose of use, has been pushed to the reconstruction, consuming large amounts of money Some learn. School to pursuethe so-called "front" image, the door to the few meters wide, at a costof millions of, far beyond the requirements of normal use; Some university green space and square area, of more than one hundred mu. Effortsand blundering businessethos to cater to each other, in advocating scientific spirit of the universitycampus, there are overblown.

\section{C.the science of budget management}

Some colleges and universities don't consider oneself circumstance, sources of funds for the school and the future development prospects, overemphasis on external image, blindly pursuing big innovation, from their own actual situation, not a scientific argument, do not do science budget, blind development new campus construction planning. Budget is the basic and general evaluation, lack of specific tracking, analysis and evaluation system, it is difficult to the use of money and benefits to make correct and objective evaluation. Because a lot of money in the construction of new campus mainly rely on bank loans, if there is no 
scientific and reasonable budgets, school will waste a lot of money, caused huge losses for the schools. In the case of school funds nervous, staff welfare, allowance will be decreased. Charge for this, some risks in colleges and universities, for to turn professional, sponsorship and so on, transfer fee to the parents, lead to collect fees in disorder, it is also the one of the reasons for the prohibition to collect fees in disorder. Excessive pursuit of external image, in addition, there are some school dedicated to face project, the construction process is not completely in accordance with the budget implementation, final accounts greatly over budget.

\section{SOME SUGGESTIONS ON PERFECTING THE FINANCIAL} MANAGEMENT IN THE NEW CAMPUS CONSTRUCTION

\section{A. strengthen prevention and control financing risk}

University new campus construction must adhere to the concept of comprehensive, coordinated and sustainable development. Universities in the lending decisions, must be based on the actual various colleges and universities, from the stable and sustainable development in higher education, really make lending decisions, reduce the financing risk. First, the government department dealing with financing risk in colleges and universities. Under the current system, the government should increase investment in education, ensure our country's higher education enterprise healthy and rapid development. "Education law of the People's Republic of China" 54 clear regulation: state financial education spending accounts for the proportion of gross national product (GNP), shall, with the development of national economy and fiscal revenue growth gradually increase, and the average number of students in school education cost increase gradually, guarantee the teachers' salaries and the average public expenditure per student growth. [2] therefore, our country's education career related law has specified level of public spending must be adapted to the national economy level of development.should be based on their financial situation, the development situation, our strengths.

Required for a bank loan to reasonable and legitimate, cannot blindly loans. By the amount of credit shall go through scientific argumentation,based on the school, on the basis of the overall plan for the future development, we will strictly control the loan amount, the amount of had better not exceed capacity of the school. Loans can only be used for basic construction and public facilities construction, school equipment, laboratory construction, etc., cannot be used to improve employee welfare treatment.

\section{B.to strengthen supervision, to establish the leadership responsibility system}

Strictly carry out, perform the college financial rules and regulations, comply with the accounting regulations, establish economic responsibility system in colleges and universities. Generally high The school's financial operation is a "unified leadership, centralized management" system, the larger schools shall practise a system of "unified leadership, graded management". School (courtyard) is the legal representative, legal responsibility for the whole university financial economic activities. Colleges and universities must be set in the bursar's office separately as a school the level of financial institutions, operators and conditions of colleges and universities to set up a chief accountant to assist the school (courtyard) long leading financial work of the school. And the chief accountant is a longer school (courtyard) unified guidance and administration under the leadership of the school of the financial work. Should establish and improve the major economic item budget review process, the major investment more than (500000), raise funds (1 million RMB) economic activity should formulate corresponding management system, by the school (courtyard) long office or the standing committee examined and approved before implementation. [3] college leadership and accounting personnel should have strong awareness of law and economy, to encourage all the staff actively involved in the construction of new campus, consciously accept their investment in the new campus direction, supervision of the construction scale, financing channels, etc. Avoid the waste of money, to ensure the construction funds to play the biggest benefit, from the source to evade the financial risks caused by excessive debt.

\section{C. scientific prediction, strict budget management}

New campus construction scale according to the school, funding sources, and the future development prospects, because of the school condition, tailors, science budget, and strict management. First of all, it should make scientific prediction and planning. Start the new campus construction in colleges and universities is a very big project, project must do a good job in all kinds of forecast and budget before determined according to the requirements of construction investment fund aggregate demand; According to its own solvency loan scale and construction scale, built the building, should not be built firmly not built, not compete with competition; Depending on the amount of time and reasonable arrangement to raise funds, the financing of time, money, put in use to connect, timely scheduling, reduce the idle capital takes up the forehead, increasing theyield of funds, avoid because capital is not implemented or unable to repay debts and lead Funding risk. Second, strengthen the budget management, the establishment of major economic project budget review process, achieve the final accounts in accordance with the budget. Construction project budget will not be able to easily change once established, should be adjusted if you want to change the time, method, procedure and so on to make the corresponding provisions. Establish a system of tracking, analysis and evaluation system, the use of money and benefits tomake correct and objective evaluation

\section{CONCLUSION}

University new campus construction to a certain extent, can realize various universities infrastructure and sharing, large-scale construction of college town was on the other hand, can cause a lot of external benefit of local government. But must be considered in the building of the new campus of colleges and universities, to fully demonstrate, scientific forecast, according to school's financial status, source of funds and the future development prospect, determine whether it is necessary to build, don't blind expansion, otherwise you will have a negative impact on the school development. New city construction must be strict budget 
management, to be consistent with the budget and final accounts for university condition, act according to actual circumstances, not blindly pursuing big innovation. Strengthen financial supervision, the construction funds for advance things afterwards whole process monitoring, ensure the constructionfunds to play the biggest economic benefits and social benefits, ensure the rapid and healthy development of education in China.

\section{REFERENCES}

[1] Wu Zhipeng. Discusses the problems in the construction of new c ampus of colleges and universities financial risk [J]. Journal of coal o f higher education, 2007, 11 (6) : 95-97.

[2] Zhao Hua. Financial management problems in the construction of new campus of colleges and universities to think [J]. Journal of xiny ang agricultural college journals. 2006, 12 (4) : 55 to 57.

Zhou Xinyong

[3], Li Hong. Financial operation of the new campus construction in colleges and universities analysis [J]. Journal of yangzhou humanism , 2007, 8 (4) : 65-67.

Zhuo measure.

[4] the construction of new campus of fundraising risk prevention [J]. Journal of chaohu college, 2007, 9 (5) : 33-36.

[5]Huang Yingxiong. An Analysis on the Best Liability Structure and Risk Control in Institutions of Higher Learning. Statistical research, 2005,3: 70-73

[6]Zou Jianbin. Risk Control of China Public Colleges and Universities loan. [D].Soochow University,2007: 1-3 